\title{
The Impact of Treated Sewage on Water Quality in Mordarka Stream
}

\author{
Karolina Kurek $^{1 *}$, Piotr Bugajski', Dariusz Młyński', Elwira Nowobilska-Majewska' \\ 1 University of Agriculture in Cracow, Department of Sanitary Engineering and Water Management, \\ al. Mickiewicza 24/28, 30-059 Kraków, Poland \\ * Corresponding author's e-mail: karolina.kurek@urk.edu.pl
}

\begin{abstract}
This paper presents the analysis and evaluation of the impact of clean sewage on the water in the Mordarka river, in the period 2012-2015. The analysis was conducted based on the collected and statistical research: the amount and composition of the purified sewage discharged to the receiver. The following pollution indices were tested: total suspended solids, $\mathrm{BOD}_{5}, \mathrm{COD}$, total nitrogen and total phosphorus. On the basis of the obtained results it was concluded that the amount of purified wastewater discharge to the Mordarka river, did not contribute to the degradation of the water quality in that period of time. Moreover, the level of indicators: total suspended solid, $\mathrm{BOD}_{5}$ and COD did not exceed the limit values from the regulation, which confirmed the effective protection of water quality in the Mordarka river. However, because of the high concentration of biogenic compounds in the purified wastewater effluents, the river is prone to eutrophication process.
\end{abstract}

Keywords: wastewater treatment plant, sewage, quality of water

\section{INTRODUCTION}

Water pollution is a serious threat to both the human health and the whole natural environment. It not only causes the limitation of water resources, but also increases the cost of water treatment for individual recipients or industry. Therefore, in order to ensure appropriate quality, water protection is nowadays one of the most important challenges posed to local governments [Piedgoń and Tchórzewska-Cieślak 2013; Policht-Latawiec and Kanownik 2013].

The main sources of pollution, causing degradation of surface water quality, include the wastewater generated as a result of ontological economic human activity. Hence, discharging untreated or dirty sewage to water receivers undoubtedly poses a threat to their entire ecosystems [Chmielowski et al., 2009; Policht-Latawiec et al., 2013; Młyński et al., 2016].

Poland, as a member state of the European Union, is obliged to implement and comply with the regulations of the Water Framework Directive
(WFD 2000). Its provisions impose an obligation concerning the rational use and protection of water resources in accordance with the principle of sustainable development on an all member states. Compliance with the provisions of WFD is aimed at restoration of the high ecological quality for water ecosystems in river basins. Implementation of the WFD provisions on the territory of Poland took place, among other things, through the amendment of the Water Law Act. There is a provision that all agglomerations with more than 2,000 equivalent inhabitants should be equipped with a collective sewage system, completed with sewage treatment plant [Wałęga et al., 2009; Miernik and Młyński 2014].

Taking into account the above-mentioned information, the goal of this work is to assess the impact of the treated wastewater, discharged from the collective treatment plant, on the quality of the receiver waters. The analysis was conducted both in the aspect of the volume of the discharged waste water, as well as in relation to the pollution loads. 


\section{CHARACTERISTICS OF THE RESEARCH OBJECT}

The considered waste treatment plant is a mechanical-biological facility situated in Mordarka (Limanowa commune, Limanowski district, Małopolskie Voivodeship) supporting 2083 $\mathrm{PE}$ in the research. Its maximum design capacity is $470 \mathrm{~m}^{3} \cdot \mathrm{d}^{-1}$. The mechanical part includes basket screens and primary settling tank. On the other hand, biological treatment processes are carried out in two reactors, operating in the technology of activated sludge and in a secondary settling tank. After the secondary settling tank, the treated wastewater is directed to the receiver - Mordarka stream.

The Mordarka stream, which is a receiver of the treated wastewater, is located in the waster region of the upper Vistula River and it is the right-bank tributary of Sowlinka - a river located in the Dunajec basin. The average annual amount of precipitation in the basin is approx. $880 \mathrm{~mm}$. The catchment area of the Mordarka stream is $16,94 \mathrm{~km}^{2}$, the length of the river is equal to $8.78 \mathrm{~km}$, the watercourse decline amounts to $34.2 \%$, and the height difference of the catchment area is 300.5 meters above sea level. The Mordarka stream's catchment area is an urbanized area, where the development surface constitutes almost $10 \%$ of the total catchment area. However, it is mainly used for the agricultural purposes $70 \%$ of the area. In turn, forests constitute $20 \%$ of its total land cover. The basin's substrate is mainly composed of impervious soils, made of: glacial tills (medium and heavy), silty clays and loams, clays of various origins, dusts of various origins, dusts, clays and loams. Figure 1 presents the diagram of hydrographic network of the Mordarka stream in the background of the catchment area's use.

\section{METHODOLOGY OF RESEARCHES}

Realization of a specific objective of the work was carried out on the basis of the provisions in [Regulation... 2014], hereinafter referred to as the Regulation, which states that the sewage entering the receiver waters should not cause physical, chemical or biological changes that would hinder the proper functioning of water ecosystems and fulfillment of specific quality requirements by water. According to [Długosz and Gawdzik 2012], a negative impact of the treatment plant on the quality of the aquatic environment is significantly reduced when the volume of
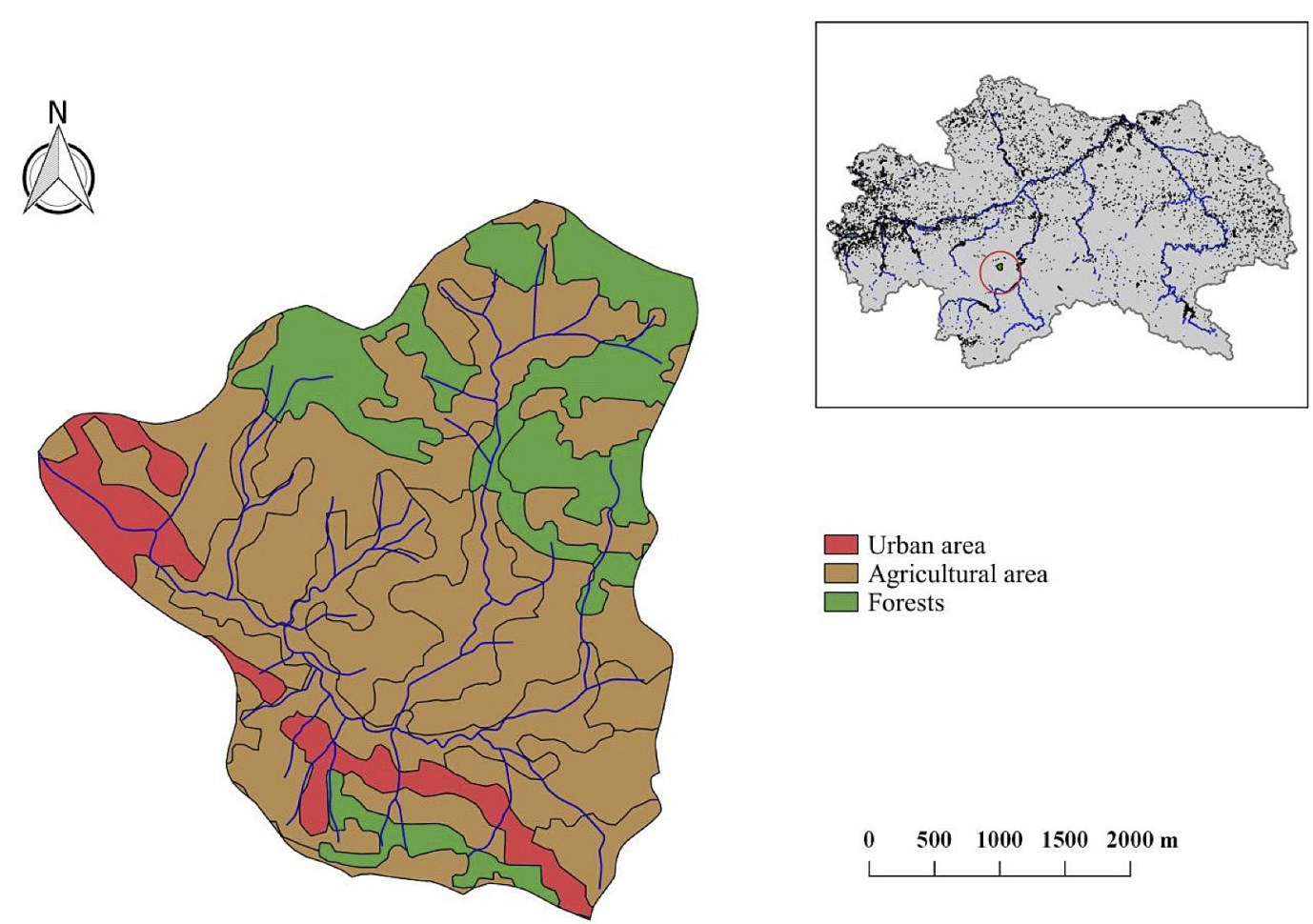

Figure 1. Diagram of hydrographic network of the Mordarka stream in the background of the catchment area's use 
the discharged wastewater does not exceed $10 \%$ of medium low flow (SNQ) of the receiver and when the quality of treated wastewater meets the requirements of the Regulation. Therefore, in this paper, the conclusion was based on the volume of wastewater discharged from the treatment plant to the Mordarka stream $\left(\mathrm{Q}_{\mathrm{d}}\right)$ and results of the analyses of the physical and chemical composition for purified wastewater samples, including: $\mathrm{BOD}_{5}$, COD, general slurry, general nitrogen and general phosphorus. The source data included the multi-year period 2012-2015.

The authoritative flow to determine the degree of dilution for the wastewater introduced into surface waters is SNQ flow [Walkowicz 1988]. Since the Mordarka stream is an uncontrolled watercourse, the size of this flow was calculated in accordance with the Stachỳ formula [Byczkowski 1999]:

$$
\begin{gathered}
S N Q=4,068 \cdot 10^{-4} \cdot A^{1,045} \cdot S S_{q g}^{0,96} . \\
\cdot i_{r}^{0,11}(1+J e z)^{0,23}\left[\mathrm{~m}^{3} \cdot \mathrm{s}^{-1}\right]
\end{gathered}
$$

where: $A$ - catchment area of the stream in $\mathrm{km}^{2}$; $S S_{q g}$ - average unit outflow (many years) coming from underground power in $\mathrm{dm}^{3} \cdot \mathrm{s}^{-1} \cdot \mathrm{km}^{-2}$, determined on the basis of [Stachỳ 1987];

$i_{r}$ - decline of watercourse in \%,

$\mathrm{Jez}$ - lake density index for the catchment area [-].

For each series of observations, including the daily outflows of the sewage from the sewage treatment plant and the values of the analyzed pollutant indices, the following descriptive statistics were determined [Młyński and Chmielows$\mathrm{ki}, 2017]$ : position measures - minimum values (min), medium $(\bar{x})$, maximum (max); measures of dispersion - standard deviation (s), coefficient of variation (Cs); measures for the shape of variable distribution - coefficient of skewness (A), kurtosis (K). All calculations were based on 29 determinants of each of the pollution indicators. Additionally, the number of exceedances for permissible the limit values of these indicators for domestic or municipal sewage discharged to the receiver (specified in the Regulation) was determined. $\left(\mathrm{N}_{\mathrm{dmax}}\right)$ was indicated according to the following formula [Heidrich 1998]:

$$
N_{d \max }=\frac{Q_{d \max }}{Q_{\text {davg }}}
$$

For the years 2012-2015, the value of the maximum daily unevenness coefficient for a daily amount of treated wastewater where:

- $Q_{d \max }-$ maximum daily volume of treated sewage in the considered period of time $\left[\mathrm{m}^{3} \cdot \mathrm{d}^{-1}\right]$,

- $Q_{\text {davg }}$ - average daily volume of treated sewage in the considered period of time $\left[\mathrm{m}^{3} \cdot \mathrm{d}^{-1}\right]$.

The analysis was supplemented with the determination of the technological purification effectiveness $\left(P_{s w}\right)$ indicator and the risk of negative operation of the sewage treatment plant $R_{s o}$. The technological purification effectiveness indicator is determined as the quotient of the number of pollutant samples consistent with the requirements of the Regulation and the total number of tested samples [Miernik and Wałęga 2006]:

$$
P_{s w}=\frac{n_{z}}{N} \frac{n_{z}}{N}
$$

where: $n_{z}$ - number of samples meeting the requirements of the Regulation concerning the quality of sewage discharged, $N$ - number of all tested samples.

The risk of negative operation of the treatment plant was defined as the probability of exceeding the permissible value of individual pollutant indicators in sewage (outflow), in a greater number of samples than it is allowed by the applicable regulations. T is described as [Andraka 2011; Andraka and Dzienis 2013]:

$$
R_{s o}=P\left(n_{n}>n_{d o p}\right)
$$

where: $n_{n}$ - number of negatively assessed purified samples of sewage,

$n_{d o p}$ - maximum number of samples that may not meet the requirements of the Regulation.

\section{TEST RESULTS AND THEIR ANALYSIS}

Formation of the size for daily outflow of sewage in the years 2012-2015 from the analyzed sewage treatment plant to the Mordarka stream is presented in Figure 2. Table 1 shows the descriptive statistics for the volume of the sewage treated in the examined period.

The calculated flow value $S N Q$ for the Mordarka stream amounted to $0.056 \mathrm{~m}^{3} \cdot \mathrm{s}^{-1}$, which means that the daily volume of the sewage discharged to the receiver should not exceed 480 $\mathrm{m}^{3} \cdot \mathrm{d}^{-1}(10 \%$ of $S N Q)$. Therefore, the maximum 


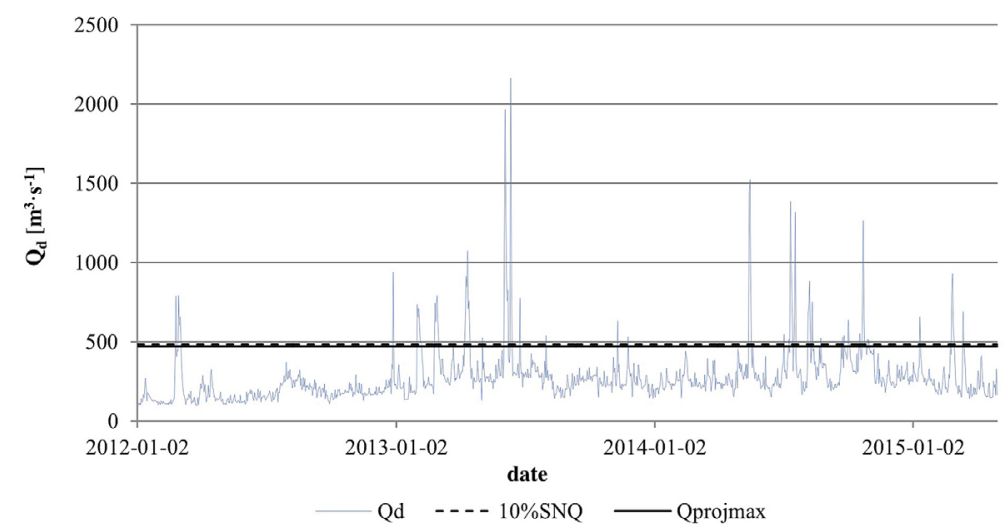

Figure 2. The amount of the effluent sewage from the tested treatment plant to the Mordarka stream in the years 2012-2015

Table 1. Characteristics of sewage effluent from the tested sewage treatment plant in the years 2011-2015

\begin{tabular}{|c|c|c|c|c|c|c|c|}
\hline$Q_{d m i n}\left[\mathrm{~m}^{3} \cdot \mathrm{s}^{-1}\right]$ & $\begin{array}{c}Q_{d \dot{s} r} \\
{\left[\mathrm{~m}^{3} \cdot \mathrm{s}^{-1}\right]}\end{array}$ & $\begin{array}{c}Q_{d \max } \\
{\left[\mathrm{m}^{3} \cdot \mathrm{s}^{-1}\right]}\end{array}$ & $\begin{array}{c}\mathrm{s} \\
{\left[\mathrm{m}^{3} \cdot \mathrm{s}^{-1}\right]}\end{array}$ & $\begin{array}{c}\mathrm{C}_{\mathrm{s}} \\
{[-]}\end{array}$ & $\begin{array}{c}\mathrm{A} \\
{[-]}\end{array}$ & $\begin{array}{c}\mathrm{K} \\
{[-]}\end{array}$ & $\begin{array}{c}\mathrm{N}_{\text {dmax }} \\
{[-]}\end{array}$ \\
\hline 100 & 275 & 2164 & 171 & 0.62 & 4.35 & 30.35 & 7.86 \\
\hline
\end{tabular}

permissible daily hydraulic load of the sewage treatment plant is $470 \mathrm{~m}^{3} \cdot \mathrm{d}^{-1}$. On the basis of the conducted analysis, it was found that in the years 2012-2015, the daily volume of sewage discharged from the tested sewage treatment plant was characterized by a spread of $2064 \mathrm{~m}^{3} \cdot \mathrm{d}^{-1}$. According to the Mucha's classification [1994], the value of $C_{s}$ coefficient indicated a high variability of the dynamics of sewage in the analyzed years. The positive value of the skewness coefficient A presents the right-side asymmetry in the $Q_{d}$ distribution which is a consequence of the higher value $Q_{\text {davg }}$ than the median and modal value of these outflows. On the other hand, the value of kurtosis indicates the leptokurtic distribution of $Q_{d}$, with a greater concentration of daily outflows around $Q_{\text {davg. }}$. On the basis of the calculations for $N_{d \max }$ coefficient, it was found that its value significantly differs from the figures presented in the literature. In the work prepared by Myszograj and Panek [2007], it was found that for the settlement units with up to 5000 inhabitants, the $N_{\text {dmax }}$ value for project purposes is assumed at the level of 2.0. However, for the discussed wastewater treatment plant, this volume is almost four times higher. It should be emphasized that the adoption of a lower value of $N_{d \max }$ at the design stage leads to the hydraulic overload of the object during its operation. Consequently, it may affect the reduction in the efficiency of devices in the technological chain of the treatment plant [Bugajski 2006]. In the an- alyzed multiannual period, the maximum daily hydraulic capacity of the facility was exceed in 83 daily periods, which constitutes $7 \%$ in relation to the entire research period. Furthermore, it was found that the volume of effluent sewage was higher than $10 \% S N Q$ of the receiver in 76 daily periods. This constituted $6 \%$ of the examined period. However, it should be emphasized that exceedances occurred mainly in the early spring or summer period. This leads to the conclusion that these exceedances were caused by the inflow of external waters to the sewage system. In the early spring months, it was probably water from snow cover thawing, while in the summer period - their source could have been increased by the atmospheric precipitation. Infiltration waters are one of the main factors causing hydraulic overflows in the sewage treatment plants, and in consequence - the exceedance in the amount of $10 \%$ of $S N Q$ [Kaczor 2011; Kaczor et al., 2013]. However, by referring to $Q_{\text {davg }}$ in the multiannual period to $S N Q$, it was found that the average daily volume of wastewater discharged in the period 2012-2015 is less than $6 \%$ of the receiver's reliable flow. Hence, the amount of the sewage entering the receiver in the study period should not result in a deterioration of the quality status for wasters in the Mordarka stream.

In order to determine the dynamics of changes in the composition of the treated sewage in the analyzed treatment plant, descriptive statistics 
were determined for the analyzed series of observational pollution indicators. Moreover, the number of exceedances for permissible values of pollutant indicators at the outflow regulated by the Regulations $\left(D_{\mathrm{gr}}\right)$ was determined. The results of calculations are presented in Table 2 .

On the basis of the results presented in Table 2, it was found that according to the $\mathrm{Mu}-$ cha's classification [1994], the dynamics of changes in the formation of pollution indicators from the organic group $\left(\mathrm{BOD}_{5}\right.$ and $\left.\mathrm{COD}\right)$ in the years 2012-2015 remained at a low level. This is indicated by the values of $C_{s}$ coefficient. In turn, for the total suspension and biogenic indicators (TN and TP), $C_{s}$ coefficient indicates high variability of concentration for these indicators. For the studied observational series of pollution indicators, the values of skewness coefficient $A$ point at the right-sided asymmetry for the distribution of variables, except for TP, which is characterized by the left-sided asymmetry (negative value of $A$ coefficient) On the other hand, the kurtosis values for biogenic indicators pointed at the platykurtic distribution of these variables, in contrast to other indicators characterized by leptokurtic distribution (positive values of $K$ indicator). It should be noted that for $\mathrm{BOD}_{5}$, COD and total suspension, no exceedance of permissible values at the outflow was observed - mandated by the Regulation. However, in the case of biogenic indicators, these exceedances were observed in the majority of the examined samples. The analysis was supplemented by determining the treatment plant operation reliability indicators: technological purification efficiency $P_{s w}$ and the risk of negative purification assessment $R_{s o}$. The calculation results are summarized in Table 3 .

By analyzing the results summarized in Table 3, it was found that in relation to the pollution indicators from the organic group and total suspension, the tested facility showed correct and reliable operation. This is evidenced by the values of $P_{s w}$ and $R_{s o}$ coefficients. Particularly unfavorable course of $R_{s o}$ size was noted for the biogenic pollution indicators. The values much greater than 1.0 indicate that the number of samples not meeting the quality requirements in accordance with the Regulation was significantly higher than the permissible number established in the current regulations (according to the Regulation for 29 measurements - maximum: 4). Hence, there is a very high risk of negative assessment of purification for sewage in relation to total nitrogen and total phosphorus. It is assumed that the increased values of TN in the effluent may have been caused by the performance of nitrification processes at the temperature of sewage lower than $12^{\circ} \mathrm{C}$. According to Bugajski [2008] and Bugajski et al. [2015], the sewage temperature is an important factor affecting the nitrogen reduction processes in the sewage treatment plants based on the activated sludge technology. At the temperature below $12^{\circ} \mathrm{C}$, there is a significant slowdown in the nitrification processes. In turn, the increased concentration of TP in the sewage (effluent) can be connected with the lack of additional installation in the treatment plant for dosing chemical agents supporting the precipitation of phosphorus.

Table 2. Descriptive statistics of tested pollution indicators in wastewater treated in the analyzed treatment plant

\begin{tabular}{|c|c|c|c|c|c|c|c|c|c|}
\hline \multirow{2}{*}{ Indicators } & \multicolumn{7}{|c|}{ Descriptive statistics } & \multirow{2}{*}{$D_{g r}$} & \multirow{2}{*}{$\begin{array}{l}\text { Number of } \\
\text { exceedances }\end{array}$} \\
\hline & $\min$ & average & $\max$ & $\mathrm{s}$ & $\mathrm{C}_{\mathrm{s}}$ & $A$ & $\mathrm{~K}$ & & \\
\hline $\mathrm{BOD}_{5}\left[\mathrm{mgO}_{2} \cdot \mathrm{dm}^{-3}\right]$ & 6.0 & 9.7 & 16.0 & 2.3 & 0.24 & 0.74 & 0.22 & 25 & 0 \\
\hline $\mathrm{COD}\left[\mathrm{mgO}_{2} \cdot \mathrm{dm}^{-3}\right]$ & 24.6 & 40.2 & 64.7 & 9.8 & 0.24 & 0.61 & 0.03 & 125 & 0 \\
\hline Total suspension $\left[\mathrm{mg} \cdot \mathrm{dm}^{-3}\right]$ & 5.0 & 12.8 & 28.0 & 5.5 & 0.43 & 0.98 & 0.96 & 35 & 0 \\
\hline $\mathrm{TN}\left[\mathrm{mgN}_{\mathrm{og}} \cdot \mathrm{dm}^{-3}\right]$ & 10.9 & 21.5 & 39.9 & 8.9 & 0.44 & 0.59 & -0.87 & 15 & 20 \\
\hline $\mathrm{TP}\left[\mathrm{mgP}_{\mathrm{og}} \cdot \mathrm{dm}^{-3}\right]$ & 0.6 & 3.2 & 5.0 & 1.4 & 0.44 & -0.44 & -0.97 & 2 & 22 \\
\hline
\end{tabular}

Table 3. Values of indicators for operational reliability in the analyzed sewage treatment plant in the years 2012-2015

\begin{tabular}{|c|c|c|c|c|c|}
\hline \multirow{2}{*}{ Reliability indicators } & \multicolumn{5}{|c|}{ Pollution indicators } \\
\cline { 2 - 6 } & $\mathrm{BOD}_{5}$ & COD & Total suspension & Nog $_{\text {og }}$ & 0.2 \\
\hline $\mathrm{P}_{\mathrm{sw}}$ & 1.0 & 1.0 & 1.0 & 0.3 & 5.5 \\
\hline $\mathrm{R}_{\mathrm{so}}$ & 0.0 & 0.0 & 0.0 & 5.0 & \\
\hline
\end{tabular}




\section{CONCLUSIONS}

On the basis of the conducted researches, it was found that in the multi-year period 2012-2015, the average volume of sewage discharged from the treatment plant to the receiver was approx. $6^{\wedge}$ of the reliable flow $S N Q$ of the Mordarka stream. Exceeding of the sewage treatment plant maximum daily flow capacity was noticed in 83 days. In the analyzed multi-year period, no exceedance of limit values for $\mathrm{BOD}_{5}$, $\mathrm{COD}$ and total suspension in the treated wastewater (according to the guidelines presented in the Regulation) was reported. However, it was found that the permissible concentration was exceeded in 20 out of 29 tested samples for eutrophic indicators, i.e. total nitrogen and total phosphorus (in $56 \%$ of sewage samples).

The conducted studies showed that the average daily volume of the sewage introduced into the Mordarka stream in the years 2012-2015 does not adversely affect the quality of the receiver waters. This means that in the studied multi-year period, the amount of the treated sewage did not change the water quality class. In terms of the rate of reduction for $\mathrm{BOD}_{5}, \mathrm{COD}$ and total suspension indicators, the sewage treatment plant was functioning properly, so that the water quality of the receiver was not degraded. Due to the high concentration of biogenic compounds, the Mordarka stream was exposed to the eutrophication processes. Therefore, it is recommended to ensure continuous monitoring related to the removal of total nitrogen and total phosphorus in the determined sewage treatment plant, as well as the quality control for receiver's waters. Moreover, it should be emphasized that due to the agricultural use of the Mordarka stream's catchment area, the biogenic compounds that infiltrate into the water by flushing from agricultural areas may constitute an additional eutrophication threat for the watercourse. Therefore, continuous monitoring of total nitrogen and total phosphorus concentrations and the susceptibility of a receiver to eutrophication seems to be justified.

\section{REFERENCES}

1. Andraka D. 2011. Modeling of wastewater treatment plant operation by means of Monte Carlo simulatio. Inżynieria Ekologiczna, nr 24, 7-16 (in Polish).

2. Andraka D., Dzienis L. 2013. Modeling of Risk in the Operation of Wastewater Treatment

3. Plants. Rocznik Ochrony Środowiska, nr 15, 1111-1125 (in Polish).

4. Bugajski P. 2006. Amount to sewage to treatment plant SBR - Biovac in Ksiaz Wielki in

5. 2000-2004 years. Infrastruktura i Ekologia Terenów Wiejskich, nr 3, 97-105 (in Polish).

6. Bugajski P., Chmielowski K., Wąsik E. 2015. Influence of atmospheric precipitations on

7. temperature and volume of wastewater in small sewage system. Infrastruktura i

8. EkologiaTerenów Wiejskich, nr 4, 1057-1066 (in Polish).

9. Byczkowski A. 1999. Hydrology tom II. Wyd. SGGW, Warszawa (in Polish).

10. Chmielowski K., Satora S., Wałęga A. 2009. Evaluation of the reliability of the sewage treatment plant for the commune of Tuchow. Infrastruktura i Ekologia Terenów Wiejskich, nr 9, 67-72 (in Polish).

11. Kaczor G. 2011. Impact of spring snowmelt on inflows to the household sewage treatment plant. Acta Sci. Pol., Formatio Circumiectus, nr 2, 27-34 (in Polish).

12. Kaczor G., Bugajski P., Bergel T. 2013. Application of the triangle method for the calculation of the infiltration and inflow volume in a sanitary sewer system. Infrastruktura i Ekologia Terenów Wiejskich, 3, 263-274 (in Polish).

13. Miernik W., Młyński D. 2014 . Analysis of the efficency of sewage treatment plant in Krzeszowice after its modernization. Episteme, nr 22, 303-310 (in Polish).

14. Miernik W., Wałęga A. 2006. Influence of operation time the efficiency of on effectiveness at sewage treatment process in Lemna sewage treatment plant. Infrastruktura i Ekologia Terenów Wiesjkich, nr 3, 39-51 (in Polish).

15. Młyński D., Chmielowski K. 2017. Analysis of the functioning wastewater treatment plant Przysieki (jasielski country) by selected statistical methods. [w:] J. Krupa, K. Szpara (red.): Zrównoważona gospodarka zasobami przyrodniczymi i kulturowymi na pogórzu Dynowskim determinantą rozwoju turystyki. Wyd. Związek Gmin Turystycznych Pogórza Dynowskiego, Dynów (in Polish).

16. Młyński D., Chmielowski K., Młyńska A. 2016. The assesment of the efficency and stability of work sewage treatment plant in Zabajka. Inżynieria Ekologiczna, nr 47, 123-130 (in Polish).

17. Mucha J. 1994. Geostatistical methods in documenting deposits. Skrypt, Katedra Geologii Kopalnianej. Wyd. AGH, Kraków (in Polish).

18. Myszograj S., Panek E. 2007. Balancing the amount of sewage reaching a sewage treatment plant. Gaz, 
Woda i Technika Sanitarna, 5, 9-12 (in Polish).

19. Piedgoń I., Tchórzewka-Cieślak B. 2013. Analysis of water supply and sewage managment in district of Błażowa within the context of implementation of the water framework directive. Czasopismo Inżynierii Środowiska i Architektury, nr 60, 79-91 (in Polish).

20. Policht-Latawiec A., Kanownik W. 2013. Quality and utility values of the Szabasowka river waters. Acta Scientiarum Polonorum Formatio Circumiectus, nr 12, 93-102 (in Polish).

21. Policht-Latawiec A., Kanownik W., Łukasik D. 2013. Effect of point source pollution on the San river water quality. Infrastruktura i Ekologia Terenów Wiesjkich, nr 1, 253-269 (in Polish).
22. Regulation of the Minister of the Environment of November 18, 2014 on the conditions to be met when introducing sewage into waters or into the ground, and on substances particularly harmful to the aquatic environment (in Polish).

23. Stachỳ J. (red.) 1987. The hydrological Atlas of Poland. Wyd. Geologiczne, Warszawa (in Polish).

24. Walkowicz J. 1988. Mean low run-off related to the catchment surface aera. Ochrona Środowiska, nr 1, 35-36 (in Polish).

25. Wałęga A., Chmielowski K., Satora S. 2009. Water and wastewater management conditio in Poland regarding water framework directive implementation. Infrastruktura i Ekologia Terenów Wiejskich, nr 4, 57-72 (in Polish). 